\title{
The Aging Human Body as a Biological or Sociocultural Reality: A Study Based on the Writings of Select Christian Philosophers and Research on the Elderly
}

Because the topic is complex, the representatives of various scientific disciples have taken up the question of the corporeality of the human person. For example, biological and medical science researchers analyze the human body as a biological phenomenon, while those in the humanities, philosophy, or the social sciences consider the socio-cultural dimensions of corporeality. This article takes the latter approach both by considering the thoughts of select Christian philosophers and analyzing results obtained from a study carried out among people aged 60 years and older in order to answer the following questions: Do the elderly perceive the human body as a biological or as a sociocultural reality? How does this same population understand the aging body? According to the results of this study, seniors perceive the human body at any age primarily as a biological reality. The way that the study participants experience the drama of aging, as St. Augustine calls it in his writings, could have influenced why they rarely consider the sociocultural dimension of aging.

Key words: the human body, the aging human body, elderly, Christian philosophy.

\section{Introduction}

Not only painters, sculptors, musicians, and other representatives of the world of art have been fascinated by the issue of human 
corporeality, but so too have those who study science and religion. Human corporeality has been analyzed from the point of view of how the body functions, its beauty or ugliness, the diseases from which it suffers, sin, debauchery, the indwelling of the soul, etc. ${ }^{1}$ These multifaceted analyses of the body reveal that the body can be treated as a biological reality, on the one hand, and as a sociocultural reality, on the other hand.

As a biological reality, the body is made up of a system of organs that are responsible for particular physiological activities. The proper functioning of these organs enables man to live well, meaning healthily. When his body functions well, man is often unaware of the biological workings of his body. However, once the functioning of the body is disturbed, which occurs in the form of health problems caused by various biological, psychological, or social factors, man notices that something is wrong. Among these factors, the aging process plays a huge role.

As a sociocultural reality, the human body is an fluid phenomenon that constantly changes. In this sense, the body is a social construct, meaning that its biology is socialized ${ }^{2}$ and it becomes the basis of social interactions and the means by which an individual becomes either incorporated into or excluded from society. The human body is also a symbolic form that reflects the norms, social hierarchies, and cultural obligations that bind an individual within a given society and at a given historical moment. ${ }^{3}$ Neither the physiological nor anatomical functions of the human body have changed for thousands of years. However, over the same amount of time, the development of civilizations "has created an amazing repertoire of practices to modify [the body]."4 These modifications have either practical applications, are undertaken in order to realize certain social corporeal ideals (e.g., the ideal beauty of the female or male body), or pertain to the sacred. ${ }^{5}$

1 J.Szymczyk, Elementy socjologiiciała, in M.Skrzypek(ed.), Socjologia medycyny wmulti-dyscyplinarnych badaniach humanizujacych biomedycynę, Wydawnictwo KUL, Lublin 2013, pg. 197.

2 P. Bourdieu, Masculine Domination, (trans.) R. Nice, Stanford: Stanford University Press, 2001, pg. 10.

3 A. Kumaniecka-Wiśniewska, Kim jestem? Tożsamość kobiet upośledzonych umystowo, Warsaw: Wydawnictwo Akademickie “Żak,” 2006, pg. 80.

$4 \quad$ K. Arcimowicz, Męskie ciało w kulturze wspótczesnej, in E. Banaszak, P. Czajkowski (eds.), Corpus delicti rozkoszne ciało. Szkice nie tylko z socjologii ciała, Difin, Warsaw 2010, pg. 122.

5 D. Majka-Rostek, Ekstremalne modyfikacje ciała, in E. Banaszak, P. Czajkowski (eds.), Corpus delicti rozkoszne ciało. Szkice nie tylko z socjologii ciała, Difin, Warsaw 2010, pg. 105. 
For a long time, the human body has undoubtedly ceased to be (insofar as it ever was) only a biological reality. Instead, it has been and continues to be both a biological and a sociocultural reality that constitutes an immanent element of man's identity, an expression of his personality, as well as an indication of his social status. ${ }^{6}$ The sociocultural dimension of human corporeality is the subject of philosophical, humanistic, and social inquiry among anthropologists, philosophers, sociologists, those who work in mass media, or the average person who observes what is happening around him. Our modern era is extremely focused on the body as a sociocultural construct. Marek Szczepanski calls modernity a body-centered culture in which self-awareness, the formation of one's identity, and one's perception of the world takes place through the body. ${ }^{7}$ This, therefore, poses the question: Is the social dimension of the body's functioning important to everyone?

This article discusses a part of the results of a survey conducted among people 60 years of age and older. The main question that will be addressed and analyzed is: How do the elderly understand the human body - as a biological or as a sociocultural reality? In addition, the survey will consider whether the respondents perceive and understand their own aging bodies (and the bodies of other seniors in general) as a biological and social phenomenon. Answers to these questions will be examined in light of the thoughts of select Christian philosophers.

\section{The Human Body in the Selected Writings of Christian Philosophers}

The greatest thinker of early Christianity, St. Augustine, often reflected on questions about the human body. When referring to the works of ancient and contemporary (for St. Augustine's time) thinkers, the Doctor of the Church (during his youth and later years) analyzed the topic of man's corporeality from different perspectives and ultimately concluded that the body and the human soul constitute a substantive union that makes up the nature of man. The Bishop of Hippo believed that "a true and complete person is not made up of just a soul or body, but both. The human body is a substantial reality in which

\footnotetext{
$6 \quad$ A. Kumaniecka-Wiśniewska, Kim jestem? Tożsamość kobiet upośledzonych umystowo..., op. cit., pg. 80.

$7 \quad$ M. S. Szczepański, G. Gawron, W. Ślęzak-Tazbir, Renta urody i tunika Nesspsa. Ciało w społecznejpercepcji, in M.S. Szczepański,B.Pawlica,A.Śliz, A. ZarębskaMazan (eds.). Ciało spieniężone? Szkice antropologiczne i socjologiczne, Tychy - Opole: Śląskie Wydawnictwa Naukowe; 2008, pgs. 55-56.
} 
the soul resides as in its own natural subject." 8 In his treatise On the Nature of Good, Augustine explained that the body and soul come from God; therefore, they are good: "Corporeality is an integral dimension of man because the body's elements and natural needs (food, clothing, shelter, etc.) are morally neutral." "Commentators on the thoughts of St. Augustine emphasize that the "According to Augustine's anthropology, man's body is interpreted as a living good: it has its own proper shape, form, harmonious build, [and] natural beauty. It is also, however, fragile in its being; it is subject to limitations, illness, and mortality." 10 According to St. Augustine, corporeality was primarily a normal and natural biological reality that serves as the basis for the soul's functioning and union with it. When writing about how the human body must undergo the difficulty of the aging process, the Bishop of Hippo saw that human biology changes with the passing of time.

Thomas Aquinas approaches man's corporeality in a different way. When analyzing the relationship that connects the soul to the body, Aquinas asserts the primacy of the soul, stating that "man is not a soul only, but something composed of soul and body. Plato supposed that sensation was proper to the soul and, therefore, maintained that man is a soul that makes use of the body." prets Aquinas' thought as such: "for St. Thomas, man is a union of soul and body, but [soul and body] are not existentially the same [...] The soul and body are two elements that are living and substantial, which together constitute the humanity of the human being. Man is a heterogeneous whole. [...] The body, as a material entity, has the ability to adopt a particular form, property, and structure. The human soul is an act of the organic body, meaning an animated body. It is not made up of material and form, but is itself the form of the body and gives it existence." ${ }^{12}$ While St. Thomas Aquinas emphasizes the psychophysical unity of the human person, he believed that the soul

$8 \quad$ S. Kowalczyk, Człowiek i Bóg w nauce św. Augustyna, Lublin: Wydawnictwo KUL, 2007, pg. 73.

St. Augustine, O naturze dobra, in Św. Augustyn, Dialogi i pisma filozoficzne. Vol IV, (trans.) M. Maykowska, Warsaw: Instytut Wydawniczy PAX, 1954, pg. 170.

S. Kowalczyk, Ciało człowieka $w$ refleksji filozoficznej, Lublin: Wydawnictwo KUL, 2009, pg. 46.

11 St. Thomas Aquinas, Treatise on Man, James F. Anderson (ed.), Englewood Cliffs, NJ: Prentice Hall Inc, 1962, pg. 7. 
is the more ontologically perfect agent whose perfection is attributed to its union with the body. ${ }^{13}$

Karol Wojtyla, who later became known as Pope John Paul II, was a contemporary personality who appreciated man's corporeality. In his reflections and writings, Wojtyla dedicated a lot of thought to man's corporeality. In accordance with St. Thomas Aquinas, Pope John Paul II believed that man is a being made up of both a body and soul. Unlike Thomas Aquinas, however, John Paul II emphasized that both aspects of human nature - the body and the soul (and not just the soul) - have dignity. "For John Paul II the body is the element of human nature that, along with the spirit, is the ontological subjectivity of man, and it participates in his personal dignity." 14 The body is "a properly personal reality, a sign and place of relations with others, with God, and with the world." ${ }^{15}$ When interpreting passages from the Holy Scripture, primarily those pertaining to the creation of man, John Paul II writes about man's sexuality as well as the physical and psychological differences between women and men who, when they come together physically, participate in the transmission of new life. According to the Pope, "the human body is a gift from God that we share with others through acts of love, goodness, and helpfulness." 16 The most perfect expression of treating one's own body as a gift is and should be the relationship that connects a woman and a man, through which they personalistically experience their love for each other. ${ }^{17}$ Moreover, according to John Paul II, "the human body is an expression of man's personality, temperament, and character; it is a language of love or hatred; it can serve either a good and higher purpose or an evil and perverse purpose." 18 The ambivalence of the body consists in the fact that, on the one hand, it is an expression of the human soul and that, on the other hand, because of original sin, it can lead to a "man of the flesh," meaning someone who uses his body in such a way that he denies his human dignity. In this sense, the Pope emphasized many issues

\footnotetext{
$13 \quad$ Ibid, pg. 49.

$14 \quad$ Ibid, pg. 118.

15 John Paul II, Evangelium Vitae, Rome, 1995, 23.

16 John PaulII, The Redemption of the Body and Saramentality of Marriage: Theology of the Body, From the Weekly Audiences of His Holiness, September 5, 1979-November 28, 1984, Available at: https://stmarys-waco.org/documents/2016/9/ theology_of_the_body.pdf [Accessed: 05.04.2018]

17 Ibid.

18 S. Kowalczyk, Z nauczania społeczno-teologicznego Papieża Jana Pawła II, Sandomierz: Wydawnictwo Diecezjalne, 2004, pg. 119.
} 
where human dignity is denied such as abortion, euthanasia, artificial reproduction, etc. While living in the modern age, the Holy Father perceived how modern men and women are very obsessed with their bodies, exhibit hedonistic attitudes, and focus on themselves and their appearances to such a degree that it seems as if they understand the body more often as a sociocultural reality than as a biological reality.

The three great thinkers mentioned above had slightly different approaches to the human body. St. Augustine perceived the human body as a biological reality; St. Thomas Aquinas believed that the body was a reality that was lower than the soul; and Pope John Paul II treated the human body as a gift from God that can be used in different ways. The following reflections on how seniors perceive the human body will subsequently reveal to which philosophical approach to human corporeality they ascribe.

\section{Research Method}

The data used in this study was obtained through research conducted in November and December 2017 among seniors aged 60 years and older. The research used quantitative method based on a survey. The questionnaire consisted of 42 questions concerning the aged human body as a biological and socio-cultural phenomenon.

The respondents were randomly chosen from among 60 -year-old (and older) residents of the Social Welfare Home [Domu Pomocy Społecznej; hereafter abbreviated as DPS] and students from the Third Age University [Uniwersytetu Trzeciego Wieku; hereafter abbreviated as UTW) in Bialystok. Study participants were separated into two groups consisting of those who reside in the DPS and are very ill and inactive, on the one hand, and those who study at the UTW and are very active and in good health, on the other hand. Both groups of people were asked to complete a survey. ${ }^{19}$ Participants were chosen randomly. In total, 100 questionnaires were collected: 46 of which were obtained from DPS residents and 54 of which were obtained from UTW students. The majority of the respondents were seniors (63\%), among whom $37 \%$ were men.

19 Some of the Residents of the Social Welfare Home helped the respondents read through and mark their responses to the questions presented in the questionnaire. Those who attend the Third Age University received the questionnaire during one of their lectures, and some of the students filled out the questionnaire on the spot, while others brought the questionnaire home, responded to the questions, and returned the questionnaire during the next lecture two weeks later. 


\section{How Seniors Perceive the Human Body}

The first question presented in the questionnaire was: "What is the human body to you?" Respondents were free to choose more than two responses (see Chart 1). Among the respondents, $79 \%$ indicated that the human body is a biological reality consisting of organs, bones, muscles, and joints; $45 \%$ indicated that the body is an "exhibit;" $16 \%$ indicated that the body is "something of which one can freely dispose;" $11 \%$ indicated that "the body is a determinant of social status;" and $5 \%$ indicated that the body suffers from disease which hinders its ability to function. It appears, therefore, that the elderly approach the human body in a "primal" way, meaning that they treat it more as a biological phenomenon than a social phenomenon. Interestingly, a few seniors thought about the body in the same way as St. John Paul II's "man of the flesh" mentioned above. The "man of flesh" presumably sees the body as an object of desire and a source of pleasure, which may not necessarily mean that he respects his dignity or the dignity of others. Most seniors do not ascribe to such an attitude toward the human body.

Chart 1 . What is the human body to you? (\%)

The body is an object of desire

The body is a source of pleasure

The body harbors disease and affects how one functions

The body is an indicator of social status

The body has capabilities that should be freely used

The body is an exhibit

The body is a biological entity made up of organs, bones, muscles, joints, etc.

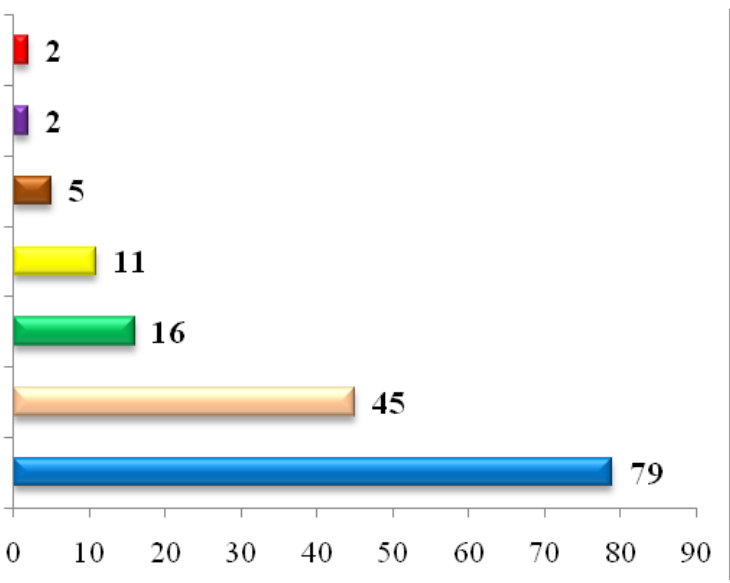

Source: author's calculation

In the following question, the respondents were asked to choose one response from those provided that they believe best defines the human body as a biological phenomenon. The elderly were expected to answer this question by looking at the corporeality of the human body through the prism of their respective and current stages of life. 
Old age is a period in life when individuals experience more than ever the deterioration of their own bodies; therefore, we anticipated that the respondents would reflect this way of thinking in the responses that they choose. It turned out, however, that all three options for responses were equally important to the respondents. According to $35 \%$ of the seniors, biologically the human body is the biological efficiency of the body, meaning health. For $34 \%$ of the respondents, biologically the body is its multitude of cells and organ systems that make up the body. Thirty-one percent of the respondents felt that biological corporeality means feeling a change in one's everyday functioning, meaning pain or bodily ailments (i.e. degeneration). Perhaps the fact that the questions stated the corporeality of the body in general and not specifically the corporeality of the aged body resulted in this distribution in the respondents' answers, which did not, unlike what was expected, confirm our hypothesis.

Chart 2. According to you, can the human body be defined today as a changing social construct that adapts to social norms? (\%)

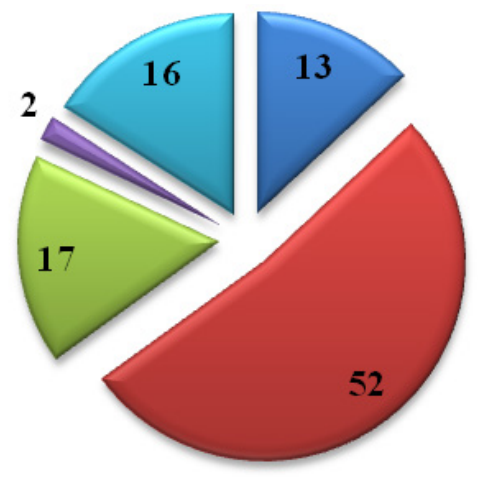
๑ Yes
\ Probably
\ Probably not
曰 No
$\square$ It is difficult to say

Source: author's calculations

Keeping in mind that some studies assert that corporeality also has a sociocultural dimension, the seniors were asked whether they thought that, in this day and age, the human body can be considered a social phenomenon that changes according to social norms. Chart 2 presents the respondents' answers, which indicate that $65 \%$ of seniors agreed with the opinion that man's corporeality can be perceived as 
a phenomenon that adapts to social norms; $19 \%$ of the respondents disagreed with such a statement; and $16 \%$ of respondents were undecided on the issue. When the respondents were asked whether the human body plays a role in determining a person's social status today, $38 \%$ of respondents said "yes," $28 \%$ responded "no," and $34 \%$ responded "I don't know." It seems, therefore, that insofar as seniors unequivocally identify human corporeality with biology, the sociocultural dimension of human corporeality is not as obvious to them.

The questions discussed so far pertained to the human body in general. In an effort to determine which understanding of the human body seniors ascribe to-whether, as stated before, they perceive the human body as a biological reality or perhaps a sociocultural reality, the respondents were asked what the aging human body of a typical senior today and what their own bodies are to them.

\section{Seniors' Perception of the Aging Body}

Graph 3 below presents the respondent's answers and indicates that $96 \%$ of them think that an aging body of a senior is something natural and normal; $91 \%$ of them also indicated that the body of a senior represents the passing of time; and $42 \%$ responded that the body is a "environment of illness and suffering."

Chart 3. What is a senior's aging body to you? (\%)

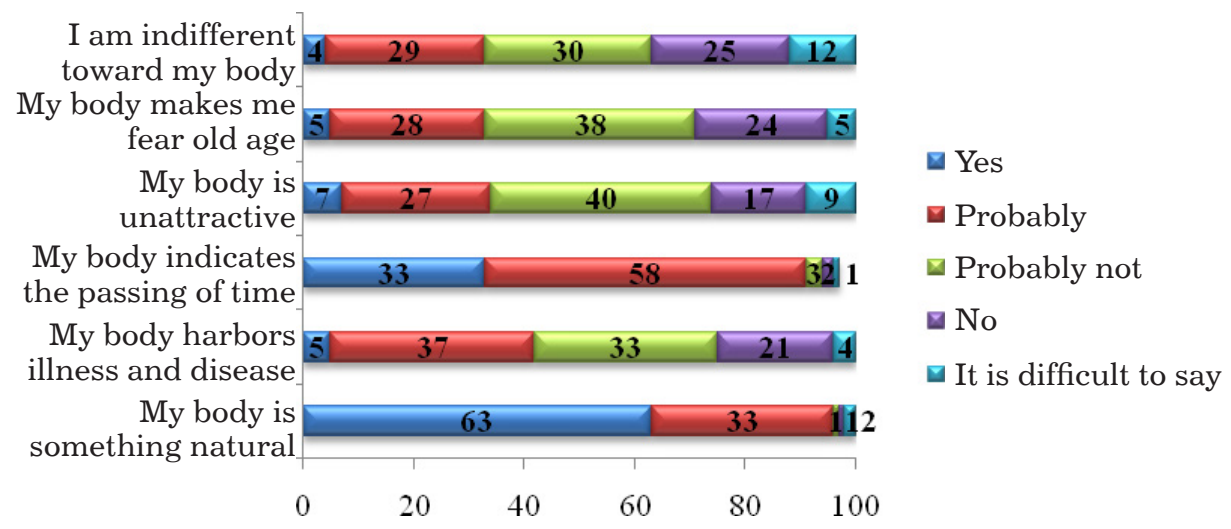

Sources: author's calculations

It appears, therefore, that the respondents did not perceive the human body from the prism of age. Their responses to the questions indicate that they perceive the human body primarily as a biological 
reality that naturally and unavoidably changes and ages with the passage of time. Although $57 \%$ of seniors disagreed with the opinion that the senior body is something unattractive, $34 \%$ of respondents expressed the opposite opinion. Physical attractiveness is certainly a sociocultural approach to corporeality. When answering various other questions about the elderly's care for the body and its appearance not mentioned in this article, the respondents indicated that, in their opinion, more senior women than men want to have a nice appearance, clothing, or figure. In addition, according to those surveyed, seniors today dress more colorfully and fashionably than seniors dressed 25 years ago, and they see that such rejuvenation of old age has many positive effects. According to the respondents, older people take care of their bodies and its appearance because they feel better both physically and mentally when they do so, and not because they wish to change their bodies to meet corporeal social expectations. Based on these responses, it is clear that the biological dimension of the body is definitely more important to seniors than the sociocultural dimension of the body. This outcome is depicted below in Chart 4 .

Chart 4. What is your body to you? (\%)

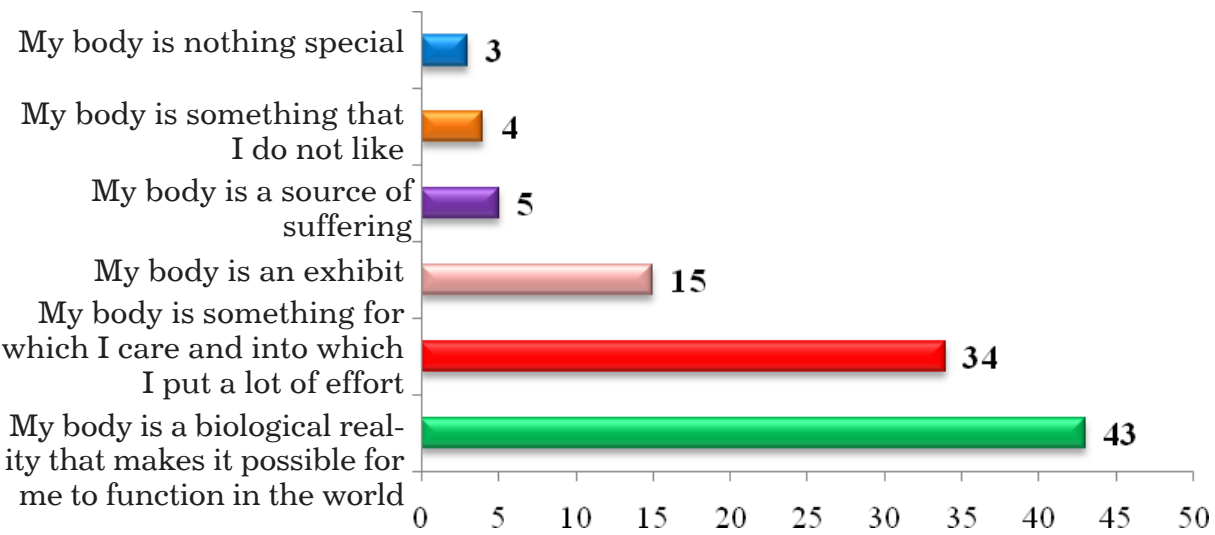

Source: author's calculations

In one of the final questions, the respondents were asked what their own bodies were to them, and they could choose no more than two responses. Of the two responses, $43 \%$ of the respondents marked "a biological reality that allows me to function in the world," while $34 \%$ marked "the object of my care and effort." The percentage of those who marked the first response reveals that seniors undoubtedly 
and primarily think that corporeality has a biological dimension. The respondents who chose the second response, suggests that they understand the body as both a biological and a sociocultural reality. The third response that only $15 \%$ of the respondents chose was "my exhibit" and refers strictly to the social dimension of corporeality. This means that almost three times fewer respondents chose the third response than those who chose the first response.

\section{Conclusion}

The research conducted among senior citizens residing in DPS and studying at the UTW indicates that they perceive the human body more as a biological than a sociocultural reality. Regardless of whether the respondents were asked specifically about the aging body or the human body in general, the biological dimension of corporeality dominated their responses. In this sense, the elderly ascribe to an understanding of the body that is closer to St. Augustine's perception of corporeality as being primarily biological. The Bishop of Hippo's very telling statement that the body experiences the drama of aging is best understood particularly by those who are living the very drama themselves. Old age is a stage in life during which biological fitness or physical disability is particularly significant. If the body functions properly from a biological point of view - that is, if it is healthy - then seniors consider the sociocultural dimensions of corporeality. A person cannot simply desire to look good, have a nice hairstyle, a shapely figure, or be well dressed; rather, an individual has put in effort to achieve these ends. It is particularly difficult for the elderly to make such efforts when their physical bodies do not want to cooperate with their desires. Therefore, seniors' treatment the body primarily as a biological reality proves that they are aware of the fact that the body's biological fitness greatly determines all other activities in which they engage.

\section{(STARZEJĄCE SIĘ) CIAŁO CZŁOWIEKA - RZECZYWISTOŚĆ BIOLOGICZNA CZY SPOŁECZNO-KULTUROWA? NA PODSTAWIE PISM WYBRANYCH FILOZOFÓW CHRZEŚCIJAŃSKICH I BADAŃ WŚRÓD OSÓB STARSZYCH}

Cielesność człowieka to zagadnienie podejmowane współcześnie przez przedstawicieli różnych dyscyplin naukowych. Wynika to przede wszystkim 
z ogromnej złożoności tematu. Stąd też, reprezentanci nauk biologicznych czy medycznych analizują ciało człowieka, jako zjawisko biologiczne. Z kolei osoby z obszaru nauk humanistycznych, filozoficznych czy społecznych zajmują się zwykle społeczno-kulturowym wymiarem cielesności. Prezentowany artykuł został napisany w duchu drugiego z podejść.

Autorka pracy, odwołując się do myśli wybranych przedstawicieli filozofii chrześcijańskiej, analizuje wyniki badań przeprowadzonych wśród osób w wieku 60 lat i więcej, poszukując odpowiedzi na pytanie: czym dla osób starszych jest ciało człowieka - rzeczywistością biologiczną czy społeczno-kulturową? Czym jest dla badanych starzejące się ciało? Prowadzone analizy wiodą do wniosku, że badani seniorzy odbierają ciało człowieka przede wszystkim jako rzeczywistość biologiczną. I nieważne, czy pytano ich o ciało człowieka w ogóle, czy o ciało starzejące się. Można przypuszczać, że doświadczanie przez ankietowanych dramatu starzenia się ciała - o czym pisał św. Augustyn, mogło mieć wpływ na rzadsze zwracanie przez nich uwagi na społeczno-kulturowy wymiar cielesności.

Słowa kluczowe: ciało człowieka, starzejące się ciało człowieka, ludzie starzy, filozofia chrześcijańska.

\section{Bibliography:}

1. Arcimowicz K., Męskie ciało w kulturze wspótczesnej. in E. Banaszak, P. Czajkowski (ed.), Corpus delicti rozkoszne ciało. Szkice nie tylko z socjologii ciała, Warsaw: Wydawnictwo Difin, 2010, pgs. 122-144.

2. Bourdieu P., Masculine Domination, (trans.) R. Nice, Stanford: Stanford University Press, 2001.

3. John Paul II, Evangelium Vitae, Rome, 1995.

4. John Paul II, The Redemption of the Body and Saramentality of Marriage: Theology of the Body, From the Weekly Audiences of His Holiness, September 5, 1979-November 28, 1984. Available at: https://stmarys-waco. org/documents/2016/9/theology_of_the_body.pdf (Accessed: 05.04.2018).

5. Kowalczyk S., Z nauczania spō̄ecz̄no-teologicznego Papieża Jana Pawła II, Sandomierz: Wydawnictwo Diecezjalne, 2004.

6. Kowalczyk S., Człowiek i Bóg w nauce św. Augustyna, Lublin: Wydawnictwo KUL, 2007.

7. Kowalczyk S., Ciało człowieka $w$ refleksji filozoficznej, Lublin: Wydawnictwo KUL, 2009.

8. Kumaniecka-Wiśniewska A., Kim jestem? Tożsamość kobiet upośledzonych umystowo, Warsaw: Wydawnictwo Akademickie "Żak," 2006.

9. Majka-Rostek D., Ekstremalne modyfikacje ciata, in E. Banaszak, P. Czajkowski (ed.), Corpus delicti rozkoszne ciało. Szkice nie tylko z socjologii ciała, Warsaw: Wydawnictwo Difin, 2010, pgs. 105-121.

10. Szczepański M., Gawron G., Ślęzak-Tazbir W. (2008), Renta urody i tunika Nesspsa. Ciato w społecznej percepcji, in Ciato spieniężone? Szkice 
antropologiczne i socjologiczne, M. S. Szczepański, B. Pawlica, A. Śliz, A. Zarębska-Mazan (ed.), Śląskie Wydawnictwa Naukowe, Tychy-Opole, pgs. 55-74.

11. Szymczyk J., Elementy socjologii ciała, in M. Skrzypek (red.), Socjologia medycyny $w$ multi-dyscyplinarnych badaniach humanizujacych biomedycyne, Wydawnictwo KUL, Lublin 2013, pg. 197-222.

12. St. Augustine, "O naturze dobra." In Św. Augustyn, Dialogi i pisma filozoficzne. Vol. IV, (Trans) M. Maykowska, Warsaw: Instytut Wydawniczy PAX, 1954, pgs. 169-187.

13. St. Thomas Aquinas, Treatise on Man, James F. Anderson (ed.). Englewood Cliffs, NJ: Prentice Hall Inc, 1962, pg. 7. 